

\title{
Investigating Users’ Perspectives of Coworking Space: Cases of Bangkok CBD
}

\author{
Sonthya Vanichvatana \\ Assumption University, Bangkok, Thailand
}

\begin{abstract}
Coworking space has changed working style from traditional office space to a shared working environment with different natures of knowledge professionals and industry. This style of work space has been increasingly popular during the past decade in major cities across the globe including the Central Business District (CBD) of Bangkok, Thailand. The initial investment of this type of business is not complex. Hence, the survival of this type of business is not easily guaranteed because of not only high competitiveness but also unclear information from the user side. Entrepreneurs of coworking spaces need to understand the characteristics and perspectives of users which may differ in various regions and cultures. This research investigated the users of coworking spaces in terms of their characteristics, behaviors, and perspectives. The scope focused on coworking spaces locating on or closed to the mass train transit stations of CBD Bangkok. The research applied quantitative approach through questionnaire surveys with 300 respondents during November, 2017. There are many interesting results found from the analysis and somehow differ from past studies. The majority of respondents were younger than 25 years old who were students. However, a quarter of those were "Corporate Employee”. Coffee shop was the top place to work outside own office, seconded by coworking spaces. The behaviors of the majority of the respondents included: $80 \%$ visited coworking spaces at least one a week and almost half visited 3-4 times a week; they spent at least three hours per visit and about $15 \%$ spent longer than six hours. The perspectives of most respondents were used coworking spaces to increase productivity and chose a place based on location. The results call for further analysis and studies.
\end{abstract}

Keywords: Bangkok CBD (Central Business District), coworking, coworking space, entrepreneur, user perspective

\section{Introduction}

\section{Rational}

Coworking spaces, as a type of office environment, have been increasingly popular for the past decades, especially in major cities around the world. In 2011, more than 700 coworking spaces open worldwide (Deskmag, 2011). However, the number has been rising sharply. According to the survey results of the global coworking conducted in 2017 (Foertsh, 2017), there are 13,800 coworking spaces throughout the world.

Office environment can differ from a small working space, like a bench in a public place, to extremely large size working space, like large multi floors office buildings. Users of office environment can also differ from one person, who is a student/start-up/independent worker/freelance, to corporate workers of any size, big or small.

Sonthya Vanichvatana, Ph.D., professor, Department of Real Estate, Martin de Tours School of Management and Economics, Assumption University, Bangkok, Thailand.

Correspondence concerning this article should be addressed to Sonthya Vanichvatana, Ramkhamkaeng 24, Huamak, Bangkapi, Bangkok, Thailand. 
There have been a number of past research to study behaviors of coworking space users and perspectives (Seo, Lysiankova, Ock, \& Chun, 2017; Spreitzer, Bacevice, \& Garrett, 2015; Kubatova, 2016). Hence, users’ lifestyles, behaviors, and perspectives differ from one region to another and from one period to another. The behaviors and/or characteristics found in one country might be differed to the other. That is different countries, different context.

\section{Research Objective}

The aim of this research is to investigate the characteristics and perspectives of users of coworking spaces. The aspects investigated include characteristics of users, behaviors of using coworking spaces, and perspective why use and choose a working place.

\section{Research Scope}

This study focused on coworking spaces located within walking distance from Bangkok Mass Transit Skytrain (BTS) stations. BTS runs through Central Business District (CBD) of Bangkok, Thailand.

\section{Literature Review}

Coworking space is defined as a shared workspace where diverse groups of freelancers, remote workers, and other independent professionals work together (Spreitzer et al., 2015; Butler, 2008). This section examines: (1) coworking spaces as a type of work environment, (2) comparing between coworking spaces and traditional office spaces, (3) cases of coworking spaces in Bangkok.

\section{Coworking Spaces as a Type of Work Environment}

Coworking space is one type among many forms of work environment: Home Office, Virtual Office, Coworking Spaces, Leased Offices, and Purchased Office (Coloso, 2015). Coworking spaces have been popular in most top capitals of the world. The number of this type of work environment has been shown in many literatures: for U.S.A (JLL, 2016), U.K. (The Instance Group, 2016), Asia (Creffield, 2016), and Thailand, Bangkok (Ewart-James, 2016).

This type of work environment was first created in 1995 in Berlin as a physical location for hackers' community. In 1999 in New York, a pleasurable work environment was created at "42 West 24th Street" with flexible desks for individuals and teams. In 2005 in San Francisco, the first official coworking space was created by Brad Neuberg (Fost, 2008). The popularity of coworking spaces is because of the rise of entrepreneurialism and a growing contingent workforce; there has been a significant shift in the way people work and where they get work done (JLL, 2016).

\section{Coworking Spaces Versus Traditional Office Place}

Coworking spaces has changed working style from traditional office space to collaborative working office space (Foertsch \& Cagnol, 2013; CBRE, 2017; Spinuzzi, 2012).

What are traditional office space like? Traditional office spaces, which can be leased office or purchased office, consist of several function areas: work space itself, meeting spaces, and support spaces, e.g., circulation and waiting areas, filling and storage spaces, print and copy area, mail area, locker area, and pantry and smoking and recreation areas (Wiki, n.d.). In fact, either leases or purchase such spaces burden corporates a certain amount of overhead costs. In addition, to lease an office space, leaser required to pay not only fixed monthly rents, on rather fixed terms, but also many types of operational costs. Such operational costs consist of fitting out costs, car parking, electricity, telephone and communication costs, management fee and service 
charges, and local property tax (CBRE, n.d.). These fixed large amounts of costs are certainly not appropriate for startups that are freelance with no certain and/or steady incomes.

What are coworking spaces like? For coworking spaces, there are three types of settings. The first is a "Shared Office" where a business let/sublet spare desks to outsiders. The second is a "Coworking Space Business" where entrepreneurs set up office spaces solely on purpose for leasing desk-space out to renters. The last is "Coworking Incubators" where services, e.g., advising/training/funding, are added up to a merely rent out working spaces (Spare Desk, n.d.).

The rental spaces typically consist of five types of settings. The first is "Hot Desk" which is a desk available to any coworker to use on a rota system. That desk does not belong to a particular coworker. That is, hot desk, or hot desking, is really a time-sharing desk which allows rental costs to be lower than a dedicated fixed desk. Using hot desk has many benefits for startup.

The clearest advantage of using coworking is to get more flexible renting terms, on daily, weekly, or monthly basis. Users have more job control in terms of work schedule and lack of routine. Coworking spaces improves financial situation of users because of affordable rental rates. Users also feel part of a community of like-minded professionals and allow possible intrinsically social-networking built-in. Finally this type of work environment allows users to encounter a great learning environment by being surrounded by other freelancers of varying experience for asking questions and learning new things. An open environment and flexible seating increase creativity and innovation through working around with multidiscipline (Rentadesk, n.d.; Spreitzer et al., 2015; Seo et al., 2017; Waber, Magnolfi, \& Lindsay, 2014; Gandini, 2015).

However, there are several disadvantages of coworking space including: privacy, noise, time wasting for unwanted socialization, constant changes of non-fixed chairs and staffs, and high cost for concerned freelancers/unemployment. For employed officers, coworking environment may be dissimilar to office environment, such as more proper office facilities. Office employers who work in a team project but using coworking spaces, will be lacking of project guidance. In addition, workers will have to trade-off between freedom of work schedule when working at coworking and incentives to work hard and be productive when coming to office. For those who get used to work at home, they have to dress properly to come to coworking and commute to city centres where coworking spaces are normally located (Becomenomad, n.d.; Cology, 2017; O’Brien, 2016).

Seo et al. (2017) surveyed both hosts and users of coworking spaces, in South Korea, and found important factors in conducting this type of business. Hosts and users prioritized for not exactly the same factors. Hosts identified for community and communication, space and interior, service diversity, and price plan. Users identified for relationship facilitation, service diversity, price plan and networking event and party. Hence, the highest priorities for sustainable coworking space operation for both sides are relationship facilitation service diversity, and price plan.

\section{Cases of Coworking Spaces in Bangkok}

Vancihvatana (2017) recently studied the characteristics of coworking spaces in Bangkok. Based on the data collect during April and May of 2017 via google maps and popular social webs, there found the total of 67 coworking spaces. The number of coworking spaces locate in core CBD and outer CBD are about the same proportion of $44.78 \%$ (30 propjects) and $43.28 \%$ (29 projects), respectively. And, coworking spaces that locate in non-CBD is the least proportion of $11.94 \%$ (6 projects). In term of the projects that locate on main road or 
close to main road, core CBD coworking spaces have the highest proportion (83\% of 30 projects), then outer CBD (66\% of 29 projects), and then non-CBD (50\% of 6 projects).

In term of operating hours, the open hours range from 7:00 am to 11:00 am. The majority of projects open at normal business hours of 8:00 am/8:30 am/9:00 am. The close hours vary wildly from 5:00 pm to midnight. Most projects have closing hours between 6:00 pm and 10:00 pm.

In term of types of spaces for rents, all projects studied offer similar workspace for rent consisting of both open spaces (hot desk and fixed desk) and enclosed space (private office, meeting room, and event room). The rental rates vary widely based on membership, size of room, and contract term. Nevertheless, rental rates for hot desk are the lowest comparing to the other types of spaces for rents, in every areas in Bangkok. Rental rates are categorized into three groups: maximum rates, average rates, and minimum rates. The maximum rental rates of core $\mathrm{CBD}$ are the highest rates, then maximum rental rates of outer $\mathrm{CBD}$, and then those of non-CBD.

Facilities/Equipments of coworking spaces consist of 17 types which can be categorized in four groups: (1) basic facilities, (2) office equipment, (3) business support, and (4) supporting space. Basic facilities consist of Wi-Fi, drinks, and snacks. Office equipment consists of printing, projector, white board, and free PC. Business supports consist of mail box, locker, business address, extra storage, direct line, and access card. Lastly, supporting spaces/activities consist of lounge seats, workshop, reading corner, TV, and theater room. The top five facilities/equipments are Wi-Fi (free), snacks and drinks, printing, mail box, and projectors. The least two ones are theater room and free PC.

\section{Methodology}

The research applied quantitative research approach through questionnaire surveys. The total of 300 sets of questionnaires were distributed at six coworking spaces located within walking distance from six Bangkok Mass Transit Skytrain (BTS) stations.

The BTS line mainly runs within CBD Bangkok areas. The chosen six stations are at the Ratchatevee, Siam Square, Chidlom, Asok, Ekamai, and Udomsuk. These surveys were conducted during November 2017. The six coworking spaces businesses provided very well corporative on this research surveys. All 300 sets of questionnaires were returned, or $100 \%$, in due time.

The survey questions are based on past works from literature reviews. The questions consist of six parts: (1) personal data, (2) behavior of users, (3) factors for choosing coworking spaces, (4) preferences of rental spaces, facilities, and services, (5) cost plan and rental rates, and (6) preferred location.

The main questions consist of as follows: (1) personal data: gender, nationality, age, category of occupation, and type of employment; (2) behavior of users: places work outside office, frequency to visit coworking spaces, duration (in hours) using a work place, and time of visits; (3) perspetives for selecting coworking spaces: top reasons to work at a coworking space, top reasons to choose a coworking place, top preferred rental spaces, and top preferred services.

\section{Findings}

From the total of 300 returned questionnaires, all respondents were Thai nationality. The following results are the findings which are describe in three parts: (1) characteristics of users, (2) behaviors of users, and (3) perspectives for selecting coworking spaces. 


\section{Characteristics of Users}

The findings about personal data consist of "Gender”, “Age”, "Category of Occupations”, and "Types of Employments".

Gender. Figure 1 shows that out of 300 questionnaires distributed in six coworking spaces. The number and percentages of male and female are 166 persons (55\%) and 134 (45\%), respectively.

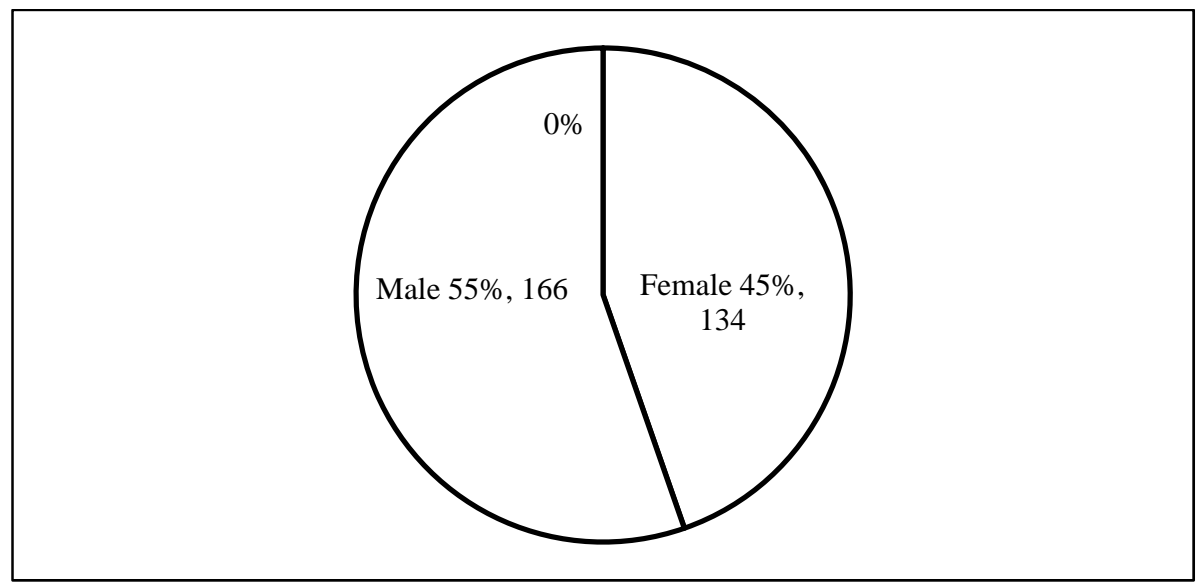

Figure 1. Gender of respondents.

Age. Table 1 and Figure 2 show ages of the respondents. The ages of the majority are 21-25 years old (125 persons, $42 \%$ ). The smaller groups by age of the respondents were those who were less than 20 years old (91 persons, 30\%), then 26-30 years old (46 persons, 16\%), then 31-35 years old (25 persons, 8\%), and then 36-40 years old (13 persons, 4\%). There was no respondent who was older than 40 years old.

Table 1

Ages of Respondents

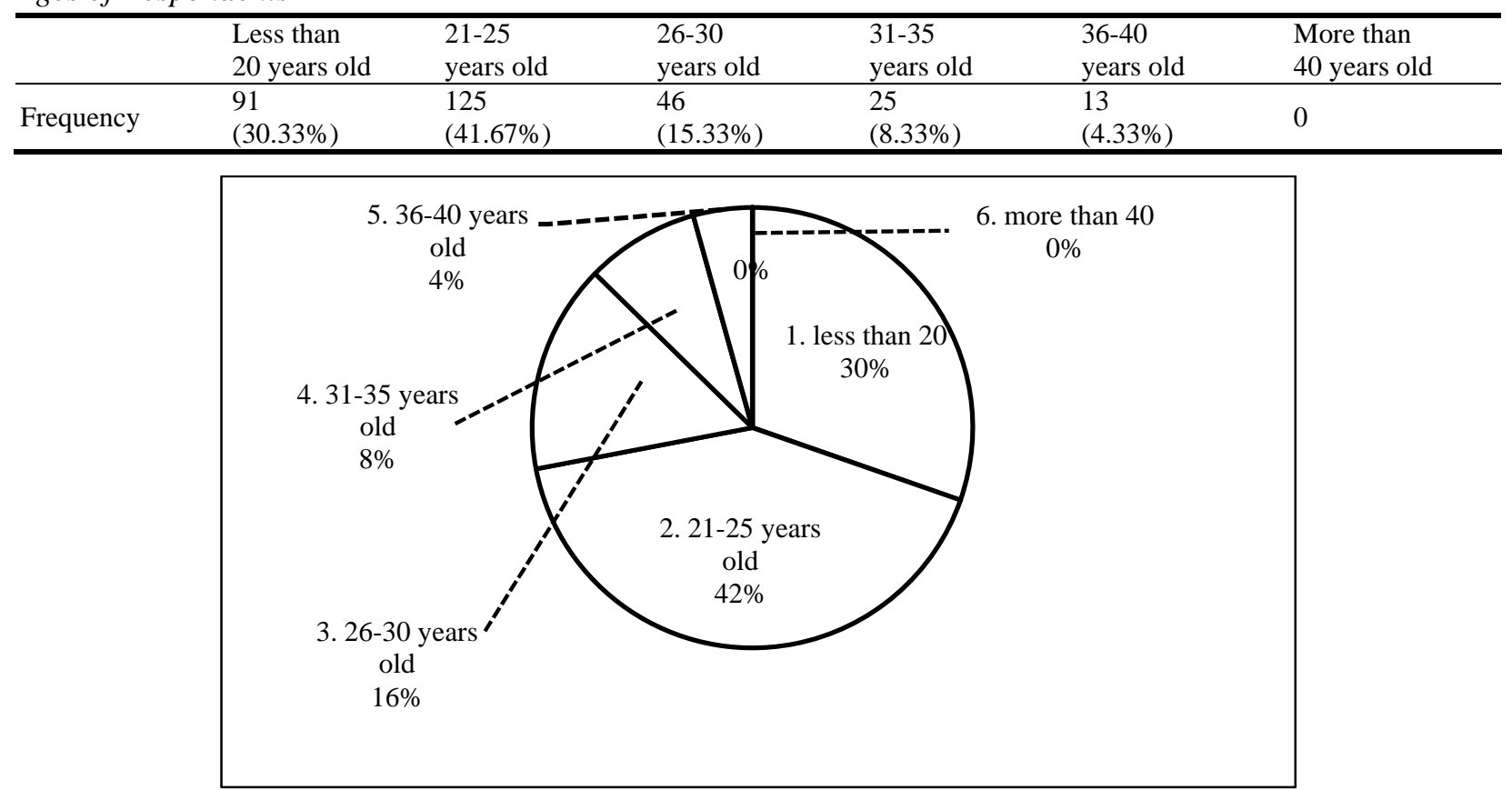

Figure 2. Age of respondents. 
Category of occupations. Table 2 and Figure 3 show the number and percentages of the respondents in category of occupations. There are six choices in the questionnaire: advertisement, designer, information technology, marketing, salesperson, and others. It is very interestingly to find that 200 respondents (67\%) chose "others" choice of Student Status. The smaller groups of occupations were salesperson (27 persons, 9\%), marketing (25 persons, 8.33\%), designer (24 persons, 8\%), information technology (15 persons, 5\%), and advertisement (9 persons, 3\%).

Table 2

Category of Occupations

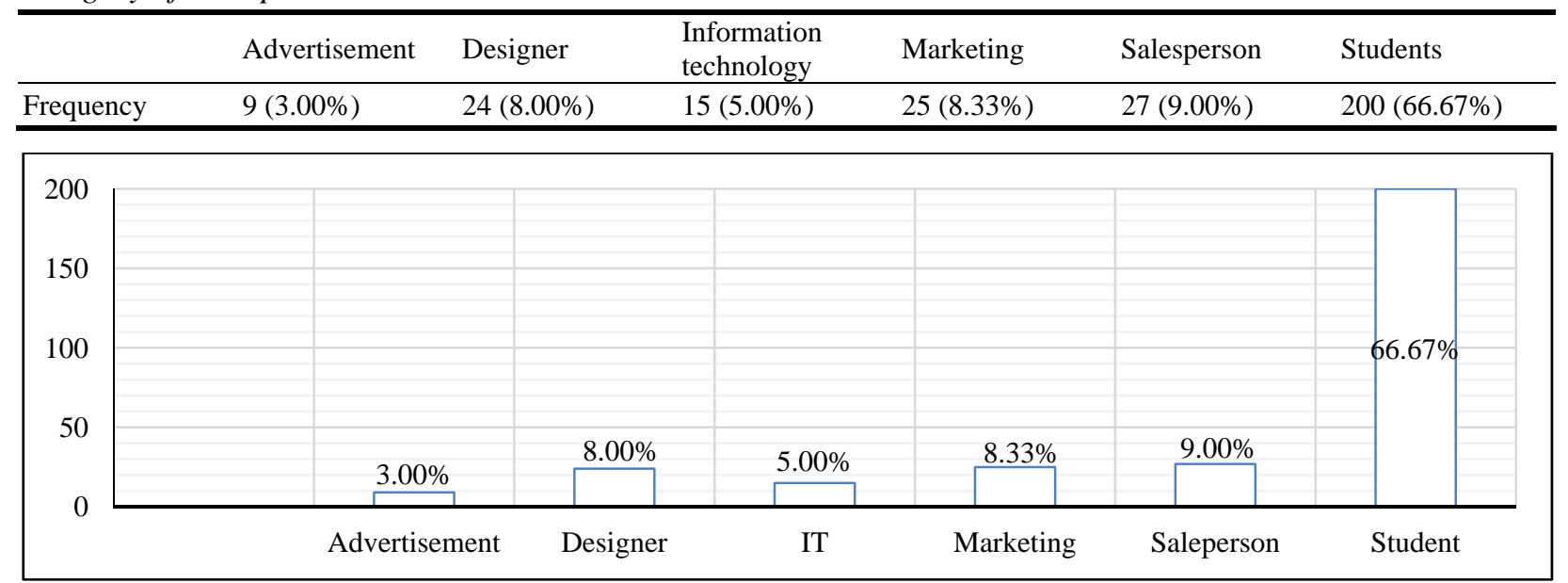

Figure 3. Category of occupations.

Types of Employments. Table 3 and Figure 4 show the finding about types of employment with five choices: business owner, corporate employee, freelance, temporary employee, and others. The majority chose "others" choice (178 person, 58\%). The smaller groups of types of employment were corporate employee (70 persons, 23\%), business owner (19 persons, 6\%), freelancers (31 persons, 10.33\%), and temporary employee (2 persons, $0.67 \%)$. It is also very interesting to find that about a quarter of respondents are "Corporate Employee".

Table 3

Types of Employment

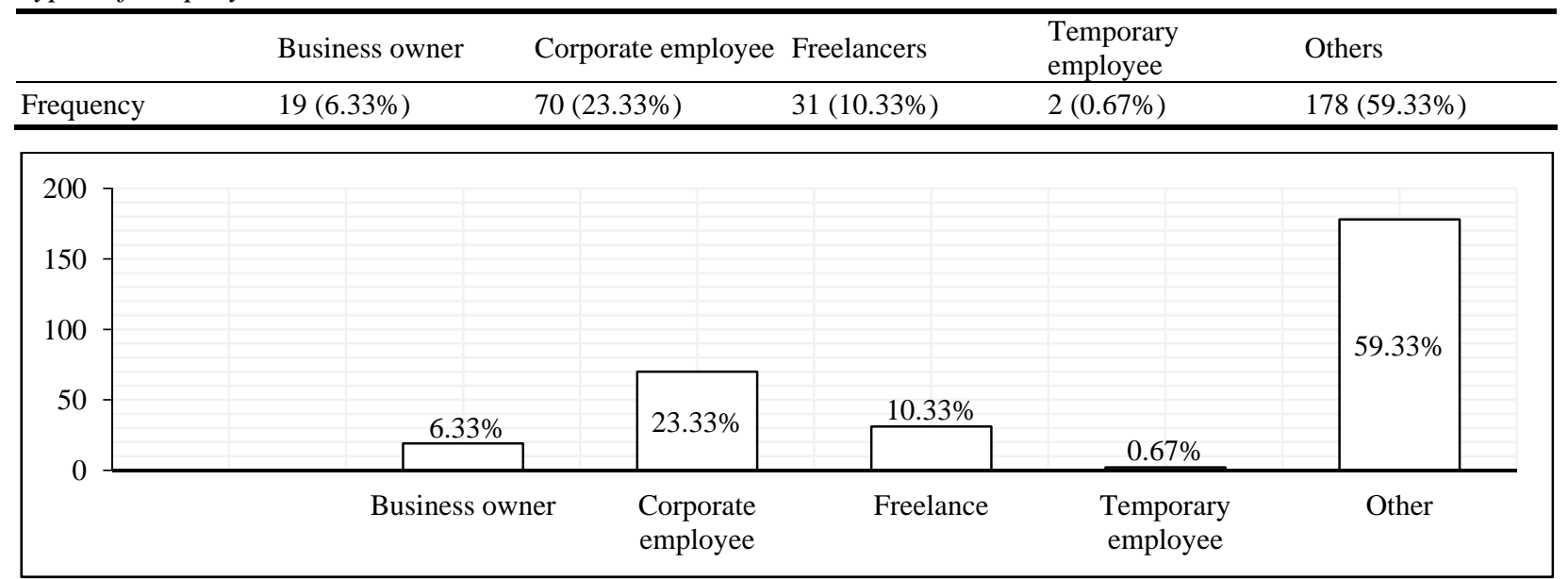

Figure 4. Types of employment. 


\section{Behaviors of Users}

The findings based on the survey results are in four parts: "Places Where Users Work Outside Their Formal Office Places”, "Frequency to Visit Coworking Spaces”, "Duration (in Hours) for Each Visit at a Coworking Space”, and “Day of a Week Time of Visits”.

Places where users work outside their formal office places. Table 4 and Figure 5 show the number and percentages of places where respondents work outside their formal office places. There are six choices: coffee shop coworking spaces, home, library, park, and others. It is very interesting to find that the top choice is not coworking spaces. Instead, the first choice is coffee shop which is chosen by almost half of the samples (138 persons, 46.00\%). Coworking spaces is the second highest chosen choice (85 persons, 28.33\%). The other ranks are home (47 persons, 15.67\%), library (20 persons, 6.67\%), park (4 persons, 1.22\%), and other (6 persons, 2.99\%).

Table 4

Places Where Users Work Outside Their Office

\begin{tabular}{lllllll}
\hline & Coffee shop & Coworking spaces & Home & Library & Park & Others \\
\hline \multirow{2}{*}{ Frequency } & 138 & 85 & 47 & 20 & 4 & 6 \\
& $(46.00 \%)$ & $(28.33 \%)$ & $(15.67 \%)$ & $(6.67 \%)$ & $(1.33 \%)$ & $(2.00 \%)$ \\
\hline
\end{tabular}

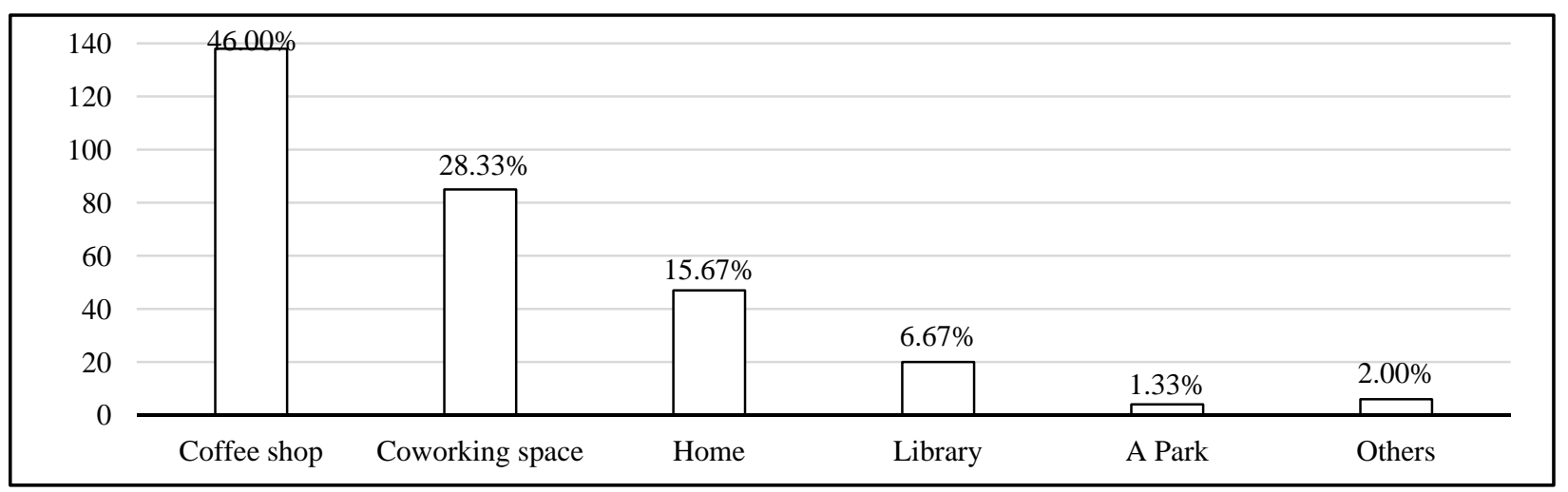

Figure 5. Places where users work outside their office.

Frequency to visit coworking spaces. Table 5 and Figure 6 show the results about how often respondents visit coworking spaces. Again, it is very interesting to find that almost half of the respondents visit coworking spaces three to four times per week $(144,48.00 \%)$. Also that, there are $5.33 \%$ of the respondents (16 persons) who visit to anyone of coworking space every day. The rest are those who visit one to two times a week (75 persons, 25.00\%); once a moth (32 persons, 14.00\%); and other unit of frequencies (23 persons, 7.67\%).

Duration (in hours) for each visit at a coworking space. Table 6 and Figure 7 show the length, in hours, that respondents spend time for each visit at a coworking space. The findings are that "less than 1 hour" is 10 persons (3.33\%), “1-2 hours” is 49 persons (16.33\%), “3-4 hours” is 122 persons (40.67\%), "5-6 hours” is 75 persons (25.00\%), and "more than 6 hours" is 44 persons (14.67\%).

The mode is between three to four hours (122 persons, 40.67\%). Only less than 20\% (59 persons, 19.99\%) spent time at a place less than two hours per visit. And, almost $80 \%$ of the respondents spent time at a place three hours up. About $15 \%$ of the respondents even spent time longer than six hours. This finding in this part is important—it reflects that majority of users are seriously coworkers. 
Table 5

Frequency to Visit Coworking Spaces



Figure 6. Frequency to visit coworking spaces.

Table 6

The Duration (in Hours) for Each Visit at a Coworking Space

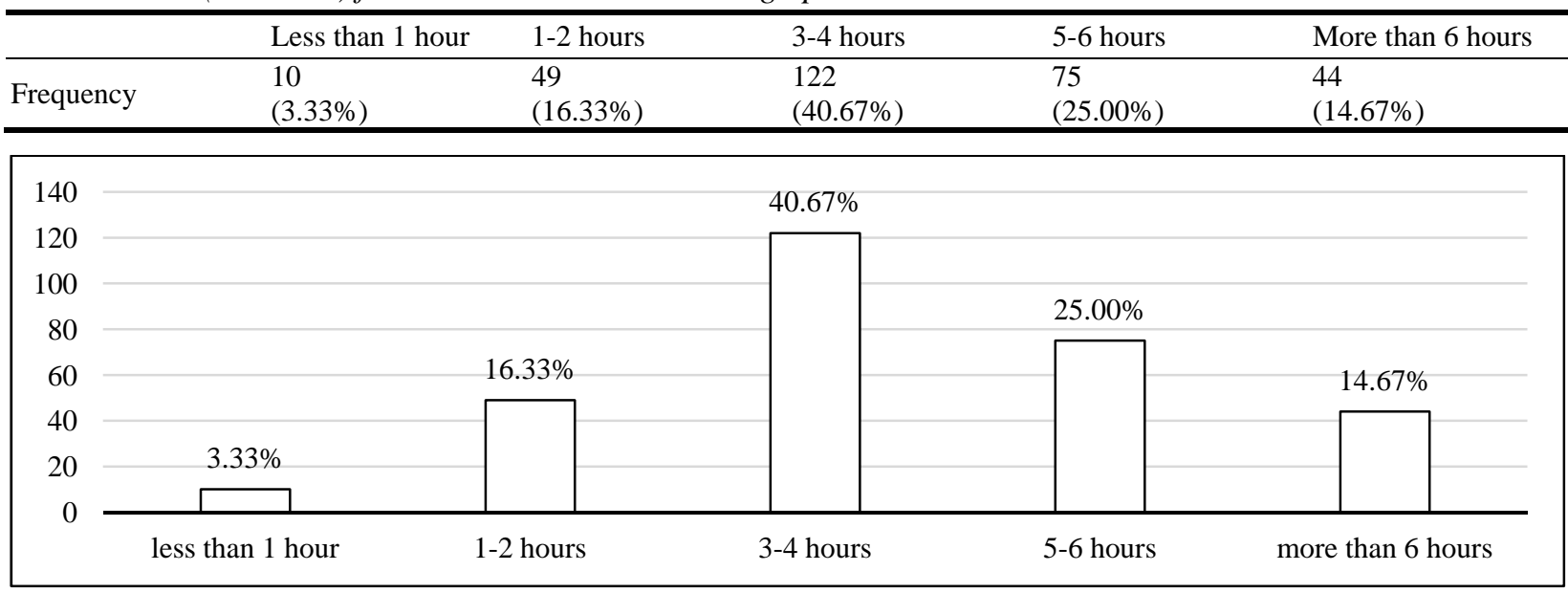

Figure 7. The duration (in hours) for each visit at a coworking space.

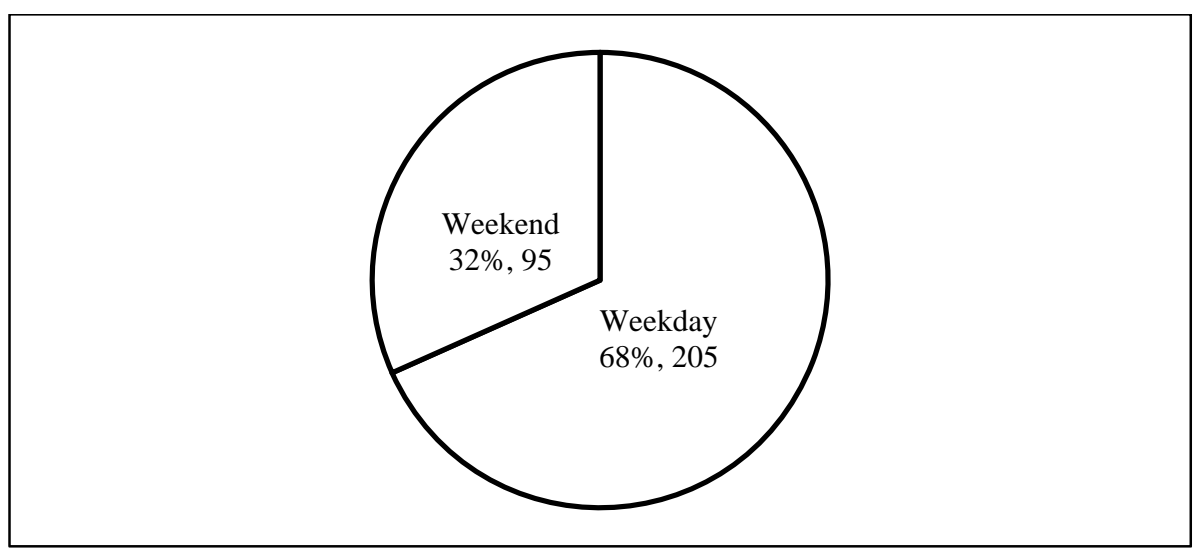

Figure 8. Day of the week of visits. 
Day of a week time of visits. From the total of 300 respondents, about $68 \%$ or 205 persons visited coworking spaces during weekday. The rest of 95 persons, about 32\%, visited the places during weekend.

\section{Perspectives for Selecting Coworking Spaces}

The followings describe four parts of findings: “Top 3 Reasons to Work at Coworking Spaces”, "Top 3 Reasons to Select a Coworking Space”, “Top 3 Types of Preferred Work Spaces”, and “Top 5 Types of Preferred Services".

Top 3 reasons to work at coworking spaces. Table 7 summaries results from the survey in this question. There are 10 choices: Increase Productivity, Decrease Loneliness/Isolation, Flexible Work Time, Share Knowledge/Idea, Network Potential, Increase Sense of Community, Mobility, Reduce Office Overhead, Can Work in CBD, and Others. Respondents were asked to rank any of the above top three choices as reasons to work at coworking spaces.

Table 7

Top 3 Reasons to "Work” at Coworking Spaces

\begin{tabular}{lllll}
\hline Factors & Chosen as 1st rank & Chosen as 2nd rank & Chosen as 3rd rank & Not chosen \\
\hline Increase productivity & 116 & 49 & 37 & 98 \\
& $(38.67 \%)$ & $(16.33 \%)$ & $(12.33 \%)$ & $(21.67 \%)$ \\
Decrease loneliness/isolation & 43 & 44 & 45 & 168 \\
& $(14.33 \%)$ & $(14.67 \%)$ & $(15.00 \%)$ & $(56 \%)$ \\
Flexible work time & 29 & 88 & 42 & 141 \\
& $(9.67 \%)$ & $(29.33 \%)$ & $(14.00 \%)$ & $(47.00 \%)$ \\
Share knowledge/idea & 28 & 40 & 38 & 194 \\
Network potential & $(9.33 \%)$ & $(13.33 \%)$ & $(12.67 \%)$ & $(64.67 \%)$ \\
& 23 & 7 & 13 & $(85.67 \%)$ \\
Increase sense of community & $(7.67 \%)$ & $(2.33 \%)$ & $(4.33 \%)$ & 223 \\
Mobility & $(7.33 \%)$ & 27 & 28 & $(74.33 \%)$ \\
& 14 & $(9.00 \%)$ & $(9.33 \%)$ & 218 \\
Reduce office overhead & $(4.67 \%)$ & $(7.00 \%)$ & $(17.67 \%)$ & $(72.67 \%)$ \\
& 12 & 9 & 11 & 268 \\
Can work in CBD & $(4.00 \%)$ & $(3.00 \%)$ & $(3.67 \%)$ & $(89.33 \%)$ \\
& 7 & 12 & 25 & 256 \\
Others & $(2.33 \%)$ & $(4.00 \%)$ & $(8.33 \%)$ & $(85.33 \%)$ \\
\hline
\end{tabular}

The lists in Table 7 are based on factors selected as the top (the 1st) choice. The top chosen factor is "Increase Productivity”, 116 persons (38.67\%). The 2nd, 3rd, and 4th ranks are "Decrease Loneliness/Isolation” (43 persons, 14.33\%), "Flexible Work Time” (29 persons, 9.67\%), and "Share Knowledge/Idea” (28 persons, 9.33\%), respectively. The 5th and the 6th ranks are with similar size of 23 persons (7.67\%) and 22 persons (7.33\%), respectively. The 7th to the 10th ranks are "Mobility", "Reduce Office Overhead", "Others", and “Can Work in CBD” with results 14 persons/4.67\%, 12/4.00\%, 10/3.33\%, and 7/2.33\%, respectively.

Majority of Thai coworkers, 38.67\%, use the spaces to increase productivity. This finding is quite dissimilar to the findings in literature reviews (Spreitzer et al., 2015; Spinuzzi, 2012) that identified top factors to work at coworking spaces are for socialize, sense of community, and or network potential.

Top 3 reasons to select a coworking space. Table 8 shows the top three reasons that respondents use to select coworking space. There are 10 choices: "Location", "Types of Services", "Price”, "Roomy Work Spaces”, “Interior Design Style”, “Supporting Equipment”, “Furniture”, “Friendliness of Staffs”, “Free Drinks”, 
and "Others". Respondents were asked to rank any of the above top three choices as reasons to select a coworking space.

Table 8

Top 3 Reasons to "Select" a Coworking Space

\begin{tabular}{|c|c|c|c|c|}
\hline Factors & Chosen as 1st rank & Chosen as 2nd rank & Chosen as 3rd rank & Not chosen \\
\hline Location & $\begin{array}{l}104 \\
(34.67 \%)\end{array}$ & $\begin{array}{l}48 \\
(16.00 \%)\end{array}$ & $\begin{array}{l}46 \\
(15.33 \%)\end{array}$ & $\begin{array}{l}102 \\
(34.00 \%)\end{array}$ \\
\hline Types of services & $\begin{array}{l}43 \\
(14.33 \%)\end{array}$ & $\begin{array}{l}22 \\
(7.33 \%)\end{array}$ & $\begin{array}{l}26 \\
(8.67 \%)\end{array}$ & $\begin{array}{l}209 \\
(69.67 \%)\end{array}$ \\
\hline Price & $\begin{array}{l}42 \\
(14.00 \%)\end{array}$ & $\begin{array}{l}89 \\
(29.67 \%)\end{array}$ & $\begin{array}{l}41 \\
(13.67 \%)\end{array}$ & $\begin{array}{l}128 \\
(42.67 \%)\end{array}$ \\
\hline Roomy work spaces & $\begin{array}{l}38 \\
(12.67 \%)\end{array}$ & $\begin{array}{l}42 \\
(14.00 \%)\end{array}$ & $\begin{array}{l}55 \\
(18.33 \%)\end{array}$ & $\begin{array}{l}165 \\
(55.00 \%)\end{array}$ \\
\hline Interior design style & $\begin{array}{l}30 \\
(10.00 \%)\end{array}$ & $\begin{array}{l}31 \\
(10.33 \%)\end{array}$ & $\begin{array}{l}41 \\
(13.67 \%)\end{array}$ & $\begin{array}{l}198 \\
(66.00 \%)\end{array}$ \\
\hline Supporting EQUIPMENT & $\begin{array}{l}27 \\
(9.00 \%)\end{array}$ & $\begin{array}{l}33 \\
(11.00 \%)\end{array}$ & $\begin{array}{l}31 \\
(10.33 \%)\end{array}$ & $\begin{array}{l}209 \\
(69.67 \%)\end{array}$ \\
\hline Furniture & $\begin{array}{l}6 \\
(2.00 \%)\end{array}$ & $\begin{array}{l}19 \\
(6.33 \%)\end{array}$ & $\begin{array}{l}17 \\
(5.67 \%)\end{array}$ & $\begin{array}{l}258 \\
(86.00 \%)\end{array}$ \\
\hline Friendliness of staffs & $\begin{array}{l}5 \\
(1.67 \%)\end{array}$ & $\begin{array}{l}13 \\
4.33 \%)\end{array}$ & $\begin{array}{l}19 \\
(6.33 \%)\end{array}$ & $\begin{array}{l}263 \\
(87.67 \%)\end{array}$ \\
\hline Free drinks & $\begin{array}{l}3 \\
(1.00 \%)\end{array}$ & $\begin{array}{l}2 \\
(0.67 \%)\end{array}$ & $\begin{array}{l}9 \\
(3.00 \%)\end{array}$ & $\begin{array}{l}286 \\
(95.33 \%)\end{array}$ \\
\hline Others & $\begin{array}{l}3 \\
(1.00 \%)\end{array}$ & $\begin{array}{l}6 \\
(2.00 \%)\end{array}$ & $\begin{array}{l}10 \\
(3.33 \%)\end{array}$ & $\begin{array}{l}281 \\
(93.67 \%)\end{array}$ \\
\hline
\end{tabular}

The lists in Table 8 are based on factors selected as the top (the 1st) choice. The top chosen factor is "Location" which is the worldwide acceptable number one rule in real estate. The 2nd and the 3rd ranks have very close results. The 2nd rank is "Types of Services" (43 persons, 14.33\%) and the 3rd rank is "Price" (42 persons, 14\%). The 4th and the 5th ranks, relating to physical body of work spaces, also have very close results. The 4th rank is "Roomy Work Places" (38 persons, 12.67\%) and the 5th rank is "Interior Design Style" (30 persons, 10.00\%). The 6th rank is "Supporting Equipment" (27 persons, 9.00\%).

The 7th, 8th, 9th, and 10th ranks have in total very small number of persons selected as top factors. These last four ranks were chosen as the first rank by only 7 persons (5.67\%). The 7th rank is "Furniture" (6 persons, $2.00 \%)$. The 8th rank is "Friendliness of Staffs" (5 persons, 1.67\%). The 9th and the 10th ranks are tied: "Free Drinks" and "Others", 3 persons, $1.00 \%$.

Top 3 types of preferred work spaces. Table 9 shows the preferred types of work spaces for rents with six choices: “Private Office”, “Hot Desk”, “Fixed Desk”, “Meeting Room”, “Event Room”, and “Others”. Respondents were asked to rank any of the above top three choices as preferred work spaces.

The lists in Table 9 are based on factors selected as the top (the 1st) choice. Three types of work spaces are in top preferred work spaces: "Private Office", "Hot Desk", and "Fixed Desk". It is very interesting to find that "Private Office" was the top chosen factor, 92 persons/30.67\%. The total percentage of "Private Office", chosen as the 1st, 2nd, and 3rd ranks, is $82.67 \%$. Besides, the number of respondents chosen "Hot Desk" and "Fixed Desk" is similar of 82 persons (27.33\%) and 79 persons (26.33\%), respectively. "Meeting Room" and "Event Room" were chosen as preferred work spaces with 35 persons/11.67\% and 6 persons/2.00\%, respectively. 
Table 9

Top 3 Types of "Preferred Work Spaces"

\begin{tabular}{lllll}
\hline Factors & Chosen as 1st rank & Chosen as 2nd rank & Chosen as 3rd rank & Not chosen \\
\hline Private office & 92 & 85 & 71 & 52 \\
& $(30.67 \%)$ & $(28.33 \%)$ & $(23.67 \%)$ & $(17.33 \%)$ \\
Hot desk & 82 & 57 & 48 & 113 \\
& $(27.33 \%)$ & $(19.00 \%)$ & $(16.00 \%)$ & $(37.67 \%)$ \\
fixed desk & 79 & 62 & 53 & 106 \\
& $(26.33 \%)$ & $(20.67 \%)$ & $(17.67 \%)$ & $(35.33 \%)$ \\
Meeting room & 35 & 69 & 70 & 126 \\
& $(11.67 \%)$ & $(23.00 \%)$ & $(23.33 \%)$ & $(42.00 \%)$ \\
Event room & 6 & 21 & 48 & 225 \\
& $(2.00 \%)$ & $(7.00 \%)$ & $(16.00 \%)$ & $(75.00 \%)$ \\
Others & 6 & 1 & 11 & 282 \\
\end{tabular}

Table 10

Top 5 Preferred "Services" at Coworking Spaces

\begin{tabular}{|c|c|c|c|c|c|c|}
\hline Factors & $\begin{array}{l}\text { Chosen as 1st } \\
\text { rank }\end{array}$ & $\begin{array}{l}\text { Chosen as 2nd } \\
\text { rank }\end{array}$ & $\begin{array}{l}\text { Chosen as 3rd } \\
\text { rank }\end{array}$ & $\begin{array}{l}\text { Chosen as 4th } \\
\text { rank }\end{array}$ & $\begin{array}{l}\text { Chosen as 5th } \\
\text { rank }\end{array}$ & Not chosen \\
\hline 24 hours access & $\begin{array}{l}165 \\
(55.00 \%)\end{array}$ & $\begin{array}{l}55 \\
(18.33 \%)\end{array}$ & $\begin{array}{l}23 \\
(7.67 \%)\end{array}$ & $\begin{array}{l}10 \\
(3.33 \%)\end{array}$ & $\begin{array}{l}7 \\
(2.33 \%)\end{array}$ & $\begin{array}{l}40 \\
(13.33 \%)\end{array}$ \\
\hline Free parking & $\begin{array}{l}39 \\
(13.00 \%)\end{array}$ & $\begin{array}{l}59 \\
(19.67 \%)\end{array}$ & $\begin{array}{l}40 \\
(13.33 \%)\end{array}$ & $\begin{array}{l}35 \\
(11.67 \%)\end{array}$ & $\begin{array}{l}21 \\
(7.00 \%)\end{array}$ & $\begin{array}{l}106 \\
(35.33 \%)\end{array}$ \\
\hline Lounge & $\begin{array}{l}36 \\
(12.00 \%)\end{array}$ & $\begin{array}{l}81 \\
(27.00 \%)\end{array}$ & $\begin{array}{l}59 \\
(19.67 \%)\end{array}$ & $\begin{array}{l}44 \\
(14.67 \%)\end{array}$ & $\begin{array}{l}19 \\
(6.33 \%)\end{array}$ & $\begin{array}{l}61 \\
(20.33 \%)\end{array}$ \\
\hline $\begin{array}{l}\text { Sell snack \& } \\
\text { drinks }\end{array}$ & $\begin{array}{l}26 \\
(8.67 \%)\end{array}$ & $\begin{array}{l}61 \\
(20.33 \%)\end{array}$ & $\begin{array}{l}84 \\
(28.00 \%)\end{array}$ & $\begin{array}{l}49 \\
(16.33 \%)\end{array}$ & $\begin{array}{l}23 \\
(7.67 \%)\end{array}$ & $\begin{array}{l}57 \\
(19.00 \%)\end{array}$ \\
\hline Lockers & $\begin{array}{l}8 \\
(2.67 \%)\end{array}$ & $\begin{array}{l}5 \\
(1.67 \%)\end{array}$ & $\begin{array}{l}12 \\
(4.00 \%)\end{array}$ & $\begin{array}{l}25 \\
(8.33 \%)\end{array}$ & $\begin{array}{l}32 \\
(10.67 \%)\end{array}$ & $\begin{array}{l}218 \\
(72.67 \%)\end{array}$ \\
\hline Library & $\begin{array}{l}6 \\
(2.00 \%)\end{array}$ & $\begin{array}{l}15 \\
(5.00 \%)\end{array}$ & $\begin{array}{l}16 \\
(5.33 \%)\end{array}$ & $\begin{array}{l}16 \\
(5.33 \%)\end{array}$ & $\begin{array}{l}31 \\
(10.33 \%)\end{array}$ & $\begin{array}{l}216 \\
(72.00 \%)\end{array}$ \\
\hline $\begin{array}{l}\text { Extra storage for } \\
\text { rents }\end{array}$ & $\begin{array}{l}6 \\
(2.00 \%)\end{array}$ & $\begin{array}{l}3 \\
(1.00 \%)\end{array}$ & $\begin{array}{l}9 \\
(3.00 \%)\end{array}$ & $\begin{array}{l}8 \\
(2.67 \%)\end{array}$ & $\begin{array}{l}18 \\
(6.00 \%)\end{array}$ & $\begin{array}{l}256 \\
(85.53 \%)\end{array}$ \\
\hline Stationary for sell & $\begin{array}{l}4 \\
(1.33 \%)\end{array}$ & $\begin{array}{l}5 \\
(1.67 \%)\end{array}$ & $\begin{array}{l}16 \\
(5.33 \%)\end{array}$ & $\begin{array}{l}25 \\
(8.33 \%)\end{array}$ & $\begin{array}{l}30 \\
(10.00 \%)\end{array}$ & $\begin{array}{l}220 \\
(73.33 \%)\end{array}$ \\
\hline Access card & $\begin{array}{l}4 \\
(1.33 \%)\end{array}$ & $\begin{array}{l}2 \\
(0.67 \%)\end{array}$ & $\begin{array}{l}7 \\
(2.33 \%)\end{array}$ & $12(4.00 \%)$ & $\begin{array}{l}24 \\
(8.00 \%)\end{array}$ & $\begin{array}{l}251 \\
(83.67 \%)\end{array}$ \\
\hline $\begin{array}{l}\text { Use of office } \\
\text { address }\end{array}$ & $\begin{array}{l}3 \\
(1.00 \%)\end{array}$ & $\begin{array}{l}3 \\
(1.00 \%)\end{array}$ & $\begin{array}{l}6 \\
(2.00 \%)\end{array}$ & $\begin{array}{l}5 \\
(1.67 \%)\end{array}$ & $\begin{array}{l}11 \\
(3.67 \%)\end{array}$ & $\begin{array}{l}272 \\
(90.67 \%)\end{array}$ \\
\hline CCTV & $\begin{array}{l}1 \\
(0.33 \%)\end{array}$ & $\begin{array}{l}10 \\
(3.33 \%)\end{array}$ & $\begin{array}{l}25 \\
(8.33 \%)\end{array}$ & $\begin{array}{l}26 \\
(8.67 \%)\end{array}$ & $\begin{array}{l}30 \\
(10.00 \%)\end{array}$ & $\begin{array}{l}208 \\
(69.33 \%)\end{array}$ \\
\hline Others & $\begin{array}{l}2 \\
(0.67 \%) \\
\end{array}$ & $\begin{array}{l}1 \\
(0.33 \%)\end{array}$ & $\begin{array}{l}3 \\
(1.00 \%) \\
\end{array}$ & $\begin{array}{l}5 \\
(1.67 \%) \\
\end{array}$ & $\begin{array}{l}13 \\
(4.33 \%) \\
\end{array}$ & $\begin{array}{l}276 \\
(92.00 \%) \\
\end{array}$ \\
\hline
\end{tabular}

Top 5 types of preferred services. Table 10 shows the top preferred services possible to be available in a coworking spaces. There are 12 choices including: "24 Hours Access”, "Free Parking”, "Lounge”, "Sell Snack \& Drinks”, “Lockers”, "Library”, “Extra Storage for Rents”, “Stationary for Sell”, “Access Card”, “Use of Office Address", "CCTV”, and "Others”. Respondents were asked to rank any of the above top five choices as preferred services.

The lists in Table 10 are based on factors selected as the top (the 1st) choice. Although there were 12 choices to select, the four types of services were chosen by the respondents. The first list is " 24 Hours Access" with 165 person of $55.00 \%$. The 2nd, 3rd, and 4th ranks with similar percentages of chosen are "Free Parking" (39 persons, 13.00\%), “Lounge” (36 persons, 12.00\%), and "Sell Snack \& Drinks” (26 persons, 8.67\%). The 
other eight types of services were not chosen in high proportions, seeing the last column of "Not Chosen".

Perspectives about membership. When ask to choose between the preference for membership or pay-per-use, the majority of the respondents chose "Pay-per-use”, 220 persons (73.33\%), to “Membership”, 80 persons (26.67\%).

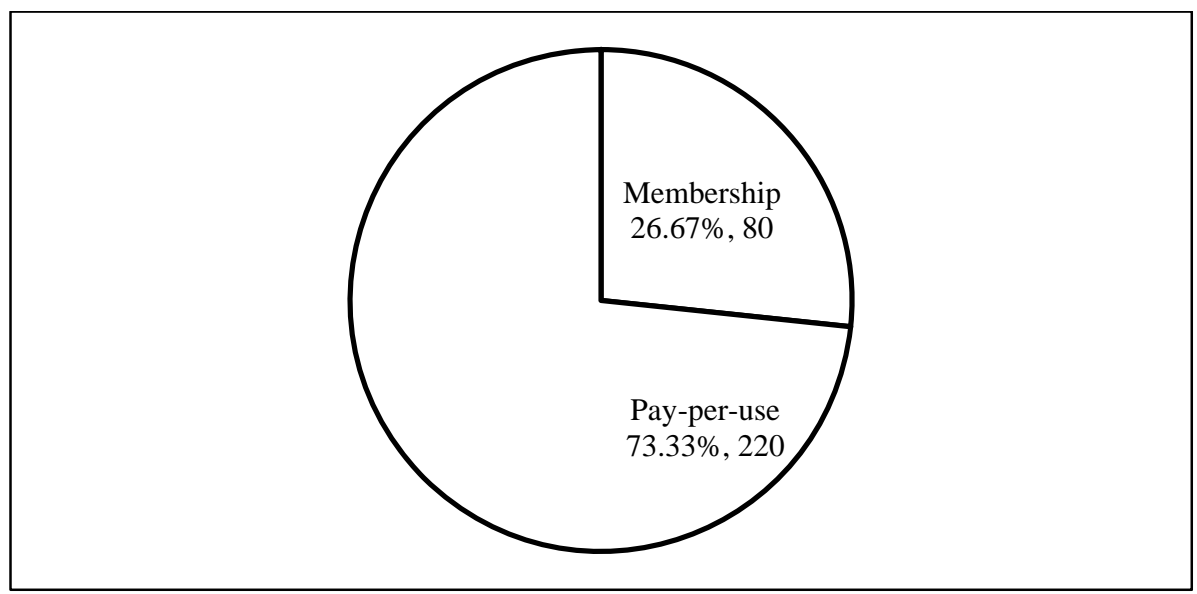

Figure 9. Perspectives about membership.

\section{Discussion}

This research findings revealed many interesting characteristics, behaviors, and perspectives of users of coworking spaces based on questionnaire surveys. Some aspects in the findings are different from those in the literature reviews. The findings are as follows:

\section{Characteristics of Users}

All respondents were Thai. There were more proportion of male to female: $55 \%$ to $45 \%$, respectively. The mode of age was 21-25 years old. Most of respondents, about 70\%, were younger than 25 years old. Surprisingly, the majority of the respondents were students, $66.67 \%$. It is also interesting to find that there were 23.33\% of respondents who were "Corporate Employee".

\section{Behaviors of Using Coworking Spaces}

"Coffee Shop" was the top place where respondents work outside their office, with $46 \%$ chosen. "Coworking Space" was the second with 28.33\% chosen. Almost half of the respondents visited coworking space three to four times per week. The total when combining the number of those who visited "Daily", "3-4 times per week", and " $1-2$ times per week" was almost $80 \%$. That is, $80 \%$ of the respondents visited a coworking space at least once per week. The majority of users spent time at a corworking space at least three hours per visit. About $15 \%$ even spent time longer than six hours. This finding in this part is important-it reflects that majority of users are seriously coworkers. There were more respondents who chose to visit coworking spaces during weekday (68\%) than weekend (32\%).

\section{Perspective Why Use and Choose a Working Place}

Majority of Thai coworkers, 38.67\%, used the spaces to increase productivity. This finding differs from the findings from several previous studies (Spreitzer et al., 2015; Spinuzzi, 2012) which indicated that one of top factors to work at coworkings is for networking. The top factor for selecting a coworking space is "Location”, which is the true rule in real estate. "Types of Services”, "Price”, and factors relating to physical of 
spaces including "Roomy Work Spaces" and "Interior Design Style” were also in top ranks. "Private Office" was found to be higher preferred type of work space than "Hot Desk". The majority of the respondents chose pay-per-use, 220 persons (73.33\%) rather than membership choice.

\section{Conclusion}

This research is limited only within Bangkok CBD context, explored during November, 2017. The research results can lead to many further researches. After this research, the database from the questionnaire surveys should be used for further analysis in order to study any linkages among numerous factors. In addition, there should be further survey extending to this work for more samples. The survey can be conducted in other CBD areas, e.g., in other BTS stations, in Bangkok. Any potential results from such research and analysis will be benefit for Thailand and academic world.

\section{References}

Becomenomad. (n.d.) Disadvantages of coworking. Become nomade. Retrieved from http://becomenomad.com/disadvantages-coworking/ [20 January 2018]

Butler, K. (2008). Works well with others. Mother Jones. Retrieved from https://www.motherjones.com/politics/2008/01/practical-values-works-well-others/ [22 May 2017]

CBRE. (n.d.). Bangkok office information. Retrieved from https://www.cbre.co.th/en/SubServices/bangkokofficerentlease [18 May 2017]

Colony. (2017). Advantages and disadvantages of co-working spaces. Colony. Retrieved from http://colony.work/advantages-disadvantages-co-working-spaces/ [20 January 2018]

Coloso, K. (2015). 5 types of offices for startups. Founder's guide. Retrieved from http://www.foundersguide.com/5-types-of-offices-for-startups/ [23 May 2017]

Creffield, L. (2016). Getting flexible: The rise of coworking in Asia. Retrieved from https://allwork.space/2016/05/getting-flexible-the-rise-of-coworking-in-asia/ [4 January 2017]

Deskmag. (2011). Number of coworking spaces increases to 700 worldwide. Coworking spaces. Retrieved from http://www.deskmag.com/en/number-of-coworking-spaces-worldwide-700 [15 August 2017]

Ewart-James, V. (2016). Co-working spaces on the up. Thailand-property. Retrieved from https://www.thailand-property.com/blog/co-working-spaces [15 August 2017]

Foertsch, C., \& Cagnol, R. (2013). The history of coworking in a timeline. Retrieved from http://www.deskmag.com/en/the-history-of-coworking-spaces-in-a-timeline [4 January 2017]

Foertsch, C. (2017). First results of the 2017 global coworking survey. Retrieved from https://www.slideshare.net/carstenfoertsch/the-first-results-of-the-2017-global-coworking-survey [10 August 2017]

Fost, D. (2008). They're working on their own, just side by side. The New York Times. Retrieved from http://www.nytimes.com/2008/02/20/business/ businessspecial2/20cowork.html [10 October 2017]

Gandini, A. (2015). The rise of coworking spaces: A literature review. Ephemera Journal, 15(1), 193-205.

JLL. (2016). Shared workspaces: The market perspective. Retrieved from http://www.us.jll.com/united-states/en-us/research/office/coworking-space-the-landlord-perspective [26 May 2017]

Kubatova, J. (2016). Human capital of the 21st century in coworking centers. In Proceeding of ECIC 2016 8th European Conference on Intellectual Capital (pp. 145-151). Venice Italy.

O’Brien, P. (2016). What are the disadvantages of co-working? Quora. Retrieved from https://www.quora.com/What-are-the-disadvantages-of-coworking [20 January 2018]

Rentadesk. (n.d.). 10 reasons why people choose our coworking spaces. Retrieved from https://www.rentadesk.co.uk/ [20 May 2017]

Seo, J., Lysiankova, L., Ock, Y., \& Chun, D. (2017). Priorities of coworking space operation based on comparison of the hosts and users’ perspectives. Sustainability, 9(1494). Retrieved from www.mdpi.com//1494/8/9/1050-2071pdf [22 August 2017]

Spare Desk. (n.d.). Different types of coworking spaces. Retrieved from http://spare-desks.com/blog/different-types-of-coworking-spaces/ [22 May 2017] 
Spinuzzi, C. (2012). Working alone together: Coworking as emergent collaborative activity. Journal of Business and Technical Communication, 26(4), 399-441.

Spreitzer, G., Bacevice, P., \& Garrett, L. (2015). Why people thrive in coworking spaces. Harvard Business Review Blog. Retrieved from https://hbr.org/2015/05/why-people-thrive-in-coworking-spaces [8 December 2017]

The Instance Group. (2016). Flexible work space review. Retrieved from http://www.theinstantgroup.com/media//209097instant_uk_sor_2016_final.pdf [26 May 2017]

Vanichvatana, S. (2017). Characteristics of co-working spaces in Bangkok. Paper presented at the Second International Research Conference on Management and Business (IRCMB). Bandung, Indonesia.

Waber, B., Magnolfi, J., \& Lindsay, G. (2014). Workspaces that move people. Harvard Business Review, 92(10), 68-77.

Wiki. (n.d.). Office. Retrieved from https://en.wikipedia.org/wiki/Office [22 May 2017] 